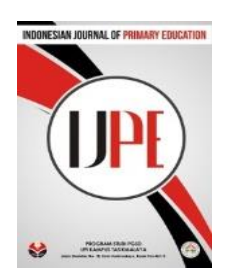

Vol. 3, No. 1 (2019) 70-80 ISSN: 2597-4866

Indonesian Journal of Primary Education

IJPE

\title{
Desain Didaktis Keliling Persegi Dan Persegi Panjang Berbasis Permainan Oray-orayan
}

\author{
Sri Maryati ${ }^{1}$, Epon Nur'aeni L ${ }^{2}$, Oyon Haki Pranata ${ }^{3}$ \\ Universitas Pendidikan Indonesia Kampus Tasikmalaya \\ *Corresponding author: marrysri61@gmail.com¹, eponalamsyah@yahoo.com², Haki_Pranata@yahoo.com³
}

Diterima 24 April; 2019; Direview 10 Mei 2019; Diterima 28 Mei 2019

Diterbitkan online 25 Juni 2019

\begin{abstract}
This research is motivated by the findings of learning obstacle experienced by students from the preliminary study related to the concept of circumference of square and rectangle. Learning obstacle causes students' understanding of the circumference of square and rectangle will experience obstacles. To resolve learning obstacle, teachers must be able to design learning in accordance with the needs of students, especially the characteristics of students of primary school age. Therefore, design didactic based the traditional game of oray-orayan can be used to facilitate students in understanding circumference of square and rectangle material, as well as an effort to preserve the increasingly extinct Indonesian culture. The aim of this research is to describe: learning obstacle of students on material circumference of square and rectangle, didactic design concept circumference of square and rectangle based on game oray-orayan, implementation didactic design of concept circumference of square and rectangle based game oray-orayan, students' responses to the didactic design concepts circumference of square and rectangle based on the oray-orayan game. The method used is the qualitative research of DDR model (Didactical Design Research), consisting of three stages: prospsective analysis, metapedadidactic analysis, and retrospective analysis. This research was conducted in fourth grade of elementary school class IV-C SDN Gunungpereng 1, and class IV-C SDN Mangkubumi. The end result of the research is teaching materials in the form of LAS (Student Activity Sheet) and RPP developed as an alternative that can be used in learning in elementary school and to overcome learning obstacle on learning mathematics in grade IV of elementary school.
\end{abstract}

Keywords: Learning Obstacle, Didactic Design, Circumference of Square and Rectangle,Traditional Game OrayOrayan, Didactical Design Research.

\begin{abstract}
Abstrak
Penelitian ini dilatarbelakangi oleh adanya temuan learning obstacle yang dialami siswa dari hasil studi pendahuluan terkait konsep keliling persegi dan persegi panjang. Learning obstacle menyebabkan pemahaman siswa terhadap keliling persegi dan persegi panjang akan mengalami hambatan. Untuk mengatasi learning obstacle, guru harus mampu merancang pembelajaran sesuai dengan kebutuhan siswa terutama karakteristik siswa usia sekolah dasar. Oleh karena itu, desain didaktis berbasis permainan tradisional oray-orayan dapat digunakan untuk memudahkan siswa dalam memahami materi keliling persegi dan persegi panjang, serta merupakan suatu upaya untuk melestarikan kebudayaan Indonesia yang semakin punah. Tujuan penelitian ini yaitu mendeskripsikan: learning obstacle siswa pada materi keliling persegi dan persegi panjang, desain didaktis konsep keliling persegi dan persegi panjang berbasis permainan oray-orayan, implementasi desain didaktis konsep keliling persegi dan persegi panjang berbasis permainan oray-orayan, respon siswa terhadap desain didaktis konsep keliling persegi dan persegi panjang berbasis permainan oray-orayan. Metode yang digunakan adalah penelitian kualitatif model DDR (Didactical Design Research), terdiri dari tiga tahap: prospective analysis, analisis metapedadidaktik, dan retrospective analysis. Penelitian ini dilakukan di kelas IV SD yaitu kelas IV-C SDN Gunungpereng 1, dan kelas IV-C SDN Mangkubumi. Hasil akhir penelitian merupakan bahan ajar dalam bentuk LAS (Lembar Aktivitas Siswa) dan RPP yang dikembangkan sebagai alternatif yang dapat digunakan dalam pembelajaran di sekolah dasar dan untuk mengatasi learning obstacle pada pembelajaran matematika di kelas IV Sekolah Dasar.
\end{abstract}

Kata kunci: Learning Obstacle, Desain Didaktis, Keliling Persegi Dan Persegi Panjang, Permainan Tradisional OrayOrayan, Didactical Design Research. 



\section{PENDAHULUAN}

Matematika merupakan suatu disiplin ilmu yang berkaitan dengan logika, besaran, pengukuran serta berbagai hal lainnya yang berhubungan dengan matematika itu sendiri. Secara umum tujuan pembelajaran matematika di sekolah dasar adalah agar siswa mampu dan terampil menggunakan matematika. Susanto (2013, hlm. 185) bahwa kebutuhan penerapan matematika saat ini dan masa depan tidak hanya keperluan sehari-hari, tetapi terutama dalam dunia kerja, dan untuk mendukung perkembangan ilmu pengetahuan. Salah satu cabang ilmu dari matematika adalah geometri. Geometri telah menjadi hal penting selama ribuan tahun bagi kehidupan manusia seperti digunakan untuk mengolah tanah, arsitektur, navigasi, serta bagi ilmu astronomi.

Geometri mulai dipelajari sejak sekolah dasar, pembelajarannya tentu meningkat mulai dari tahap pengenalan yang ada di kelas I sampai ke tahap yang lebih kompleks seperti dalam kurikulum 2013 pembelajaran geometri yang ada di kelas IV mengenai keliling persegi dan persegi panjang. Permasalahan yang muncul di sekolah dasar, sebagian besar siswa kurang berminat untuk mempelajari geometri karena menganggap geometri sulit untuk dipelajari, sehingga masih banyak siswa yang kesulitan untuk memahami konsep geometri. Sejalan dengan hal tersebut, Menurut Nur'aeni (2008, hlm.2) “kenyataan di lapangan, memperlihatkan bahwa diantara semua cabang matematika, hasil belajar siswa dalam geometri yang sangat memprihatinkan."

Apabila siswa mampu memahami materi terkait materi keliling persegi dan persegi panjang akan sangat bermanfaat bagi kehidupan sehari-hari siswa. Sejalan dengan hal tersebut, seperti yang dikemukakan oleh Usiskin (dalam Safrina, Ikhsan dan Ahmad, 2014, hlm. 10) bahwa salah satu alasan geometri perlu diajarkan karena geometri satu-satunya cabang ilmu matematika yang bisa dikaitkan dengan bentuk fisik dunia nyata.

Berdasarkan hasil studi pendahuluan yang dilakukan di SDN 1 Karangampel terhadap 26 orang siswa ditemukan hambatan belajar pada materi keliling persegi dan persegi panjang. hammbatan belajar yang dialami yakni 7,6\% siswa mengalami hambatan dalam menuliskan jenis bangun datar, 53,8\% siswa mengalami hambatan dalam menghitung keliling persegi, 84,6\% mengalami hambatan dalam menghitung keliling persegi panjang, 92,3\% mengalami hambatan dalam menyelesaikan soal yang berkaitan dengan keliling persegi panjang, serta mengalami hambatan dalam menyelesikan soal yang berkaitan dengan keliling persegi panjang. Hambatan yang dialami tersebut bisa disebabkan oleh berbagai faktor. Faktor penyebabnya adalah "kesiapan mental siswa, pengajaran guru dan pengetahuan siswa yang memiliki konteks terbatas" (Brosseau dalam 
Suryadi, 2010 hlm.2). Hambatan yang ditemukan perlu diminimalisir dengan cara membuat desain didaktis yang mengembangkan pemahaman siswa terhadap keliling persegi dan persgi panjang.

Sebagaimana yang dikemukakan oleh Suryadi (2010, hlm. 2) bahwa "keberhasilan pembelajaran antara lain terkait/erat dengan desain bahan ajar (desain didaktik) yang dikembangkan oleh guru", sehingga dalam penelitian ini peneliti berupaya merancang sebuah desain didaktik yang memenuhi kebutuhan pembelajaran dengan cara mengemas pembelajaran keliling persegi dan persegi panjang dalam sebuah desain didaktis dengan berbasis permainan tradisional orayorayan. Desain didaktis ini bertumpu pada teori perkembangan menurut Piaget dan teori tingkatan pembelajaran geometri menurut Van Hiele.

Menurut Mulyani (2016, hlm.46) Permainan tradisional merupakan hasil budaya masyarakat, yang berasal dari zaman yang sangat tua, yang telah tumbuh dan hidup hingga sekarang. Permainan tradisional bukan hanya sekedar alat permainan saja tapi mwemiliki berbagai latar belakang yang bercorak kreatif, kompetitif, pedagogis, magis dan religius.

Permainan oray-orayan merupakan salah satu permainan tradisional yang berasal dari Jawa Barat, serta mempunyai manfaat bagi kehidupan sehari-hari anak. Dengan penggunaan permainan tradisional oray- orayan diharapkan dapat memfasilitasi siswa belajar keliling persegi dan persegi panjang yang menarik dan sesuai dengan karakteristik tahap usia perkembangan siswa sekolah dasar.

Rumusan masalah dalam penelitian ini adalah dirumuskan menjadi beberapa hal diantaranya: 1) Bagaimana learning obstacle siswa pada materi keliling persegi dan persegi panjang?, 2) Bagaimana desain didaktis konsep keliling persegi dan persegi panjang berbasis permainan oray-orayan untuk kelas IV sekolah dasar?, 3) Bagaimana implementasi desain didaktis konsep keliling persegi dan persegi panjang berbasis permainan oray-orayan untuk kelas IV sekolah dasar?, 4) Bagaimana respon siswa terhadap desain didaktis konsep keliling persegi dan persegi panjang berbasis permainan oray-orayan?. Untuk menjawab rumusan masalah tersebut maka tujuan dari adanya penelitian ini adalah sebagai berikut:

1) Untuk mendeskripsikan learning obstacle siswa pada materi keliling persegi dan persegi panjang, 2) Untuk mendeskripsikan desain didaktis konsep keliling persegi dan persegi panjang berbasis permainan oray-orayan untuk kelas IV Sekolah Dasar, 3) Untuk mendeskripsikan implementasi desain didaktis konsep keliling persegi dan persegi panjang berbasis permainan oray-orayan untuk kelas IV Sekolah Dasar, 4) Untuk mendeskripsikan respon siswa terhadap desain didaktis konsep 
keliling persegi dan persegi panjang berbasis permainan oray-orayan.

\section{METODE PENELITIAN}

Metode penelitian yang digunakan adalah penelitian kualitatif dengan model Didactical Design Research (DDR). Metode ini difokuskan merancang, mengembangkan dan mengevaluasi sebuah desain tertentu sebagai solusi untuk memecahkan masalah yang ada dalam praktik pendidikan. Fokus penelitian untuk mengatasi hambatan belajar (learning obstacle) yang dialami oleh siswa dalam pembelajaran keliling persegi dan persegi panjang di kelas IV Sekolah Dasar. Langkahlangkah desain penelitian digambarkan dari segitiga matepedadidaktik Kansaen yang diadaptasi dari Aprianti, (2016, hlm. 30) adalah sebagai berikut:

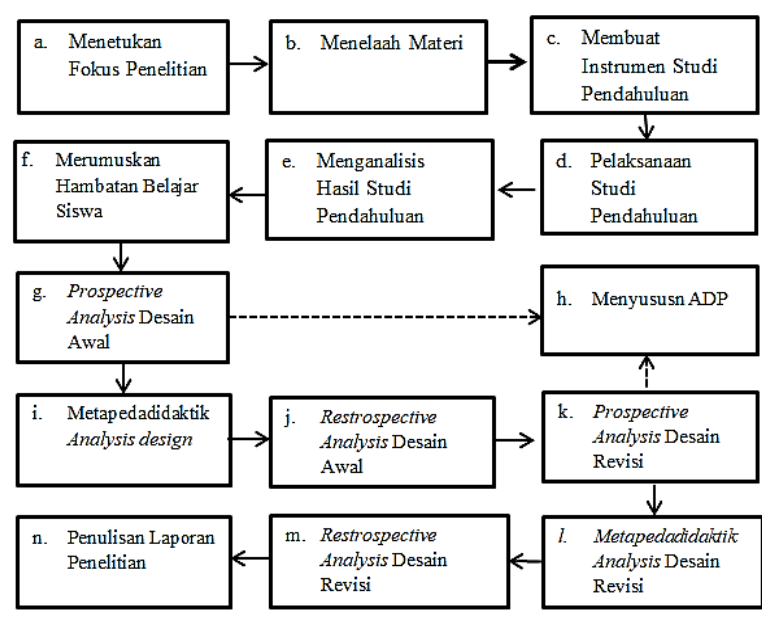

\section{Gambar 1}

\section{Bagan Desain Penelitian DDR (Diadaptasi dari Aprianti, 2016, hlm. 30)}

Langkah pertama adalah menentukan fokus penelitian dalam pembelajaran matematika di SD, kemudian memilih materi di kelas IV yaitu untuk mengembangkan pemahaman siswa terkait materi kelilling persegi dan persegi panjang. Pada tahap studi pendahuluan, instrumen yang digunakan adalah pedoman wawancara, skala sikap, serta soal terkait keliling persgi dan persegi panjang. Pelaksanaan studi pendahuluan dilaksanakan di kelas SDN 1 Karangampel terhadap 26 orang siswa. Berdasarkan hasil studi pendahuluan ditemukan hambatan belajar yang dialami siswa dalam materi keliling persegi dan persegi panjang. setelah dilakukan analisis kemudian dilakukan penyusunan bahan ajar untuk implementasi desain didaktis. Implementasi dilaksanakan dalam dua siklus yaitu implementasi desain awal dan implementasi desain didaktis revisi setelah dilakukan peninjauan kembali dari desain didkatis awal apabila masih terdapat kekurangan untuk menyempurnakan deain didaktis awal. Partisipan yang terlibat dalam penelitian ini adalah SDN 1 karangampel, SDN Gunungpereng 1, dan SDN Mangkubumi. Teknik pengumpulan data yang digunakan adalah triangulasi yakni wawancara, dokumentasi, dan observasi.

\section{HASIL DAN PEMBAHASAN}

Berikut ini akan dipaparkan hasil dan penelitian yang telah dilaksanakan mengenai dsain didaktis keliling persegi dan persegi panjang berbasis permainan tradisional orayorayan. Penelitian dilakukan di tiga sekolah dasar yang berbeda. Untuk mengunngkap hambatan belajar yang dialami siswa, maka dilaksanakan studi pendahuluan di SDN 1 
Karangampel terhadap 26 orang siswa dengan memberikan soal terkait materi keliling persegi dan persegi panjang. Berdasarkan hasil studi pendahuluan terungkap beberapa hambatan belajar yang ditemukan diantaranya adalah sebagai berikut:

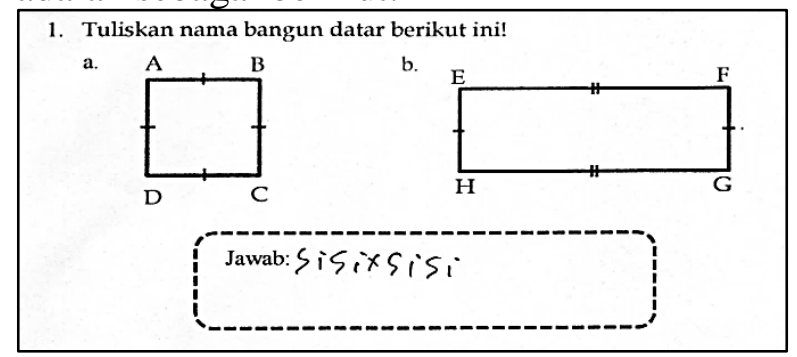

\section{Gambar 1 \\ Hambatan Belajar Tipe 1}

Hambatan belajar tersebut berkaitan dengan hambatan siswa dalam mengetahui bentuk bangun datar tertentu.

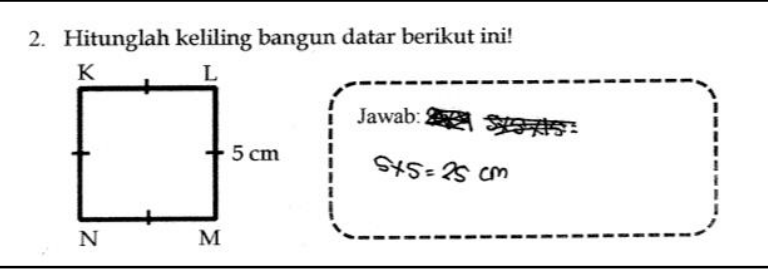

Gambar 2

Hambatan Belajar Tipe 2

Hambatan belajar tersebut berkaitan dengan keulitan siswa untuk menghitung keliling persegi.

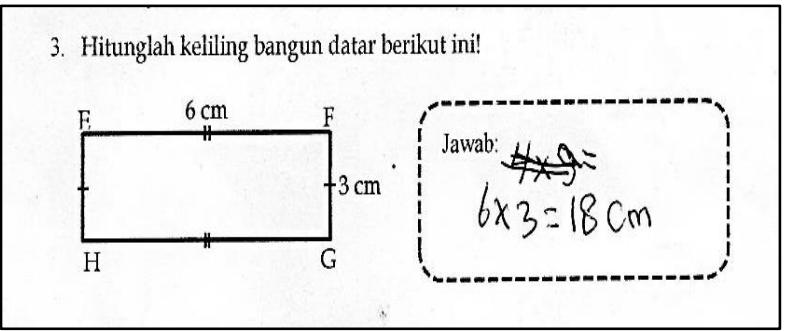

\section{Gambar 3 \\ Hambatan Belajar}

Hambatan belajar tersebut berkaitan dengan kesulitan siswa dalam menghitung keliling persegi panjang. Siswa tersebut keliru menggunakan rumus menghitung luas daerah untuk menghitung keliling persegi panjang.

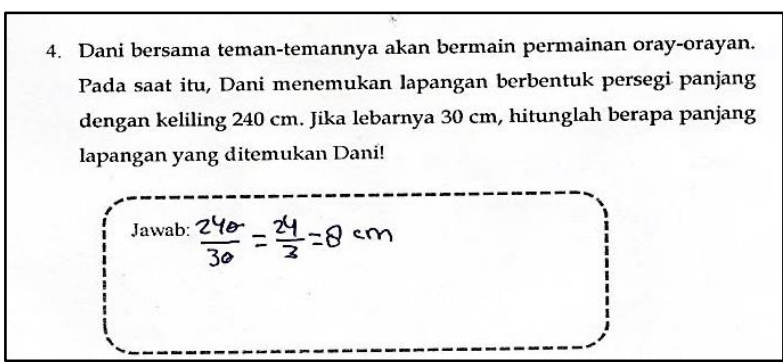

\section{Gambar 4 \\ Hambatan Belajar Tipe 4}

Hambatan belajar yang dialami oleh siswa tersebut adalah berkaitan dengan menyelesaikan soal yang berkaitan dengan keliling persegi panjang.

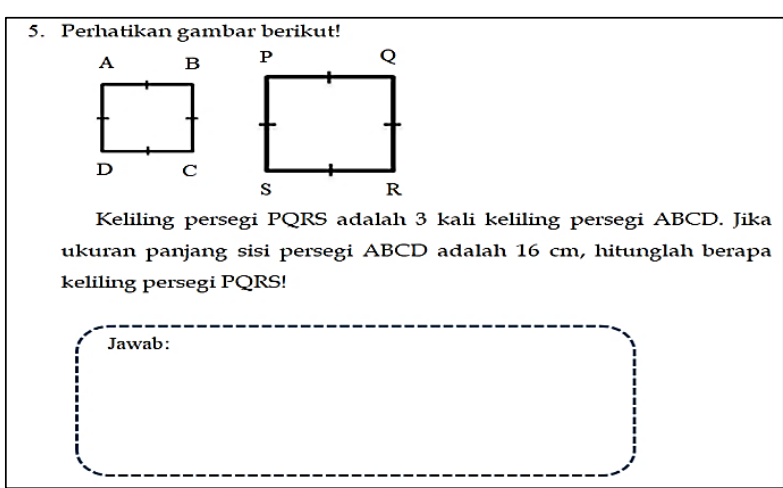

\section{Gambar 5}

Hambatan Belajar Tipe 5

Hambatan belajar tersebut berkaitan dengan kesulitan siswa dalam menyelesaikan soal yang berkaitan dengan keliling persegi.

Berbagai learning obstacle siswa yang telah dibahas sebelumnya membuktikan bahwa hambatan belajar siswa tergolong pada hambatan epistemologis yaitu, hambatan belajar yang berkaitan dengan keterbatasan pengetahuan pada konteks tertentu. Hambatan epistemologis dapat muncul ketika siswa diharuskan mengidentifikasi soal yang 
diberikan serta menentukan solusi untuk menyelesaikan soal-soal yang diberikan.

Pembelajaran yang menjadi fokus penelitian adalah materi kelilng persegi dan persegi panjang. Desain didaktis yang disusun merupakan bahan ajar berupa LAS (Lembar Aktivitas Siswa) yang dikerjakan secara berkelompok. Implementasi desain didaktis awal dilaksanakan di SDN Gunungpereng 1 terhadap 22 orang siswa.

Pertama adalah kegiatan untuk pengembangan pemahaman siswa terhadap bangun datar persegi dan persegi panjang. Kemampuan awal yang harus dimiliki siswa yaitu mengetahui konsep bangun datar terlebih dahulu sebelum mempelajari keliling persegi dan persegi panjang. Siswa menyebutkan bangun datar yang mereka ketahui seperti persegi, persegi panjang, lingkaran, segitiga, belah ketupat, dll. Pembelajaran kemudian dilanjutkan dengan siswa mengamati benda-benda di dalam kelas yang mempunyai bentuk persegi dan persegi panjang. Siswa menyebutkan papan tulis, penghapus, meja, kursi, jam dinding, lantai, tempat pensil, buku, dll. Kegiatan apersepsi ini sesuai dengan tahap berpikir geometri menurut Van Hiele yaitu tahap visualisasi atau pengenalan untuk membantu siswa menjembatani pola berpikir dari konsep abstrak menuju konkret.

Kegiatan kedua adalah untuk mengembangkan pemahaman siswa siswa melakukan permainan tradisional oray-orayan untuk lebih memahami konsep keliling. Guru mengaitkan permainan oray-orayan dengan konsep keliling bahwa kelilng diibaratkan jarak yang ditempuh dari titik dimana kita berdiri kemudian berputar sampai pada titik semula.

Setelah siswa memahami konsep keliling, kegiatan berikutnya adalah mengembangkan pemahaman siswa menghitung keliling persegi. Siswa diingatkan kembali dalam bacaan bahwa untuk mencari ukuran keliling dari suatu bangun datar adalah dengan menjumlahkan ukuran setiap sisinya. Kemudian, siswa diminta untuk berdiskusi bersama kelompoknya mengisi kolom menemukan rumus keliling persegi. Kegiatan tiga adalah mengembangkan pemahaman siswa menghitung keliling persegi. Perwakilan siswa diminta untuk mengukur petak permainan tradisional oray-orayan yang berbentuk persegi terlebih dahulu menggunakan pita ukur yang telah disediakan oleh guru. Setelah ukuran sisi petak ditemukan, setiap kelompok menuliskan ukuran petak tersebut pada kolom yang telah disediakan. Langkah selanjutnya adalah menghitung keliling petak tersebut sesuai dengan rumus yang telah dipelajari.

Kegiatan berikutnya adalah untuk Mengembangkan pemahaman siswa menemukan rumus keliling persegi panjang. Langkah-langkah kegiatan yang dilakukan tidak berbeda jauh dengan langkah-langkah menemukan rumus keliling persegi. Siswa 
mengamati kolom langkah-langkah menemukan rumus keliling persegi panjang. selanjutnya, kegiatan diarahkan untuk mengembangkan pemahaman siswa menghitung keliling persegi panjang. Kegiatan yang dilakukan adalah siswa diminta untuk mengukur petak permainan tradisional oray-orayan yang berbentuk persegi panjang. Setelah siswa menemukan ukuran dari petak permainan, siswa menuliskan ukurannya dalam kolom yang telah di sediakan dalam LAS, kemudian siswa berdiskusi bersama kelompoknya untuk menghitung berapa keliling petak tersebut. pada akhir kegiatan 2, dan 3 dalam LAS siswa mengerjakan soal evaluasi yang terdiri dari 4 butir soal.

Pada kegiatan pembelajaran desain awal masih terdapat banyak kekurangan, baik dari desain didaktis yang disusun peneliti maupun dari pemahaman siswa terhadap konteks materi. Berdasarkan hasil analisis tersebut, peneliti memperbaiki desain didaktis dengan cara melakukan repersonalisasi untuk memperbaiki bahan ajar yang akan digunakan dalam desain revisi. Beberapa hal yang diperbaiki diantaranya penambahan perintahperintah untuk memudahkan siswa melakukan kegiatan pembelajaran. Perbaikan berikutnya adalah penambahan gambar bangun datar persegi untuk menuntun siswa menemukan rumus keliling persegi, serta perbaikanperbaikan pada setiap butir soal evaluasi. Prediksi respon siswa beserta antisipasi didaktis pedagogisnya juga mengalami beberapa perbaikan.

Pembelajaran yang dilaksanakan pada desain revisi 1 tidak jauh berbeda dengan desain sebelumnya. Desain revisi dirancang peneliti lebih memfokuskan terhadap desain yang hambatan belajarnya masih muncul. Pelaksanaan desain didaktis revisi dilaksanakan pada responden yang berbeda yaitu 22 orang siswa kelas IV-C SDN Mangkubumi.

Penelitian ini berawal dari temuan learning obstacle atau hambatan belajar siswa terkait konsep keliling persegi dan persegi panjang. Hambatan belajar yang ditemukan antara lain:

Tipe 1 :Learning obstacle terkait dengan mengetahui bentuk bangun datar persegi dan persegi panjang

Tipe 2 :Learning obstacle terkait dengan menghitung keliling persegi

Tipe 3 :Learning obstacle terkait dengan menghitung keliling persegi panjang

Tipe 4 :Learning obstacle terkait dengan menyelesaikan soal yang berkaitan dengan menghitung keliling persegi

Tipe 5 :Learning Obstacle terkait dengan menyelesaikan soal yang berkaitan dengan menghitung keliling persegi panjang

Penyusunan desain didaktis awal didasarkan pada temuan learning obstacle yang ditemukan pada saat studi pendahuluan dan dipadukan dengan teori-teori belajar yang relevan. Berdasarkan teori Van Hiele 
mengenai tahapan berpikir geometri, tahap awal pembelajaran merupakan tahap pengenalan atau visualisasi bentuk bangun datar yaitu persegi dan persegi panjang, kemudian mengamati, menyebutkan, dan menuliskan bentuk petak permainan orayorayan yang mempunyai bentuk persegi dan persegi panjang (analisis). Setelah pengalaman dan pengetahuan siswa terhubung, maka kegiatan pembelajaran selanjutnya adalah penanaman konsep inti yakni menghitung keliling persegi dan persegi panjang.

Dalam merancang desain didaktis ini, peneliti berupaya mendesain pembelajaran yang mampu memfasilitasi siswa belajar mengenai keliling persegi dan persegi panjang namun menyesuaikan dengan karakteristik usia perkembangan siswa sekolah dasar yang masih senang bermain dan berada pada tahapan berpikir konkret. Berdasarkan teori pembelajaran menurut Dienes merupakan seorang matematikawan yang memusatkan perhatiannya pada cara-cara pengajaran terhadap anak-anak, membagi 6 tahapan secara berurutan dalam menyajikan konsep matematika, yaitu tahap bermain bebas, tahap permainan, tahap penelaahan kesamaan sifat, tahap representasi, tahap simbolis, tahap formalisasi. Sistem yang dikembangkannya bertujuan agar pembelajaran lebih menarik bagi siswa yang mempelajari matematika. Setiap konsep atau prinsip dalam matematika disajikan dalam bentuk konkret, sehingga obyek yang terdapat dalam permainan akan sangat bermakna apabila diolah dengan maksimal dalam pembelajaran matematika. Oleh karena itu peneliti menggunakan permainan tradisional oray-orayan sebagai sarana siswa belajar mengenai materi keliling persegi dan persegi panjang.

Penggunaan permainan tradisional orayorayan juga mempunyai manfaat bagi kehidupan siswa seperti meningkatkan keterampilan sosial anak, terutama untuk melestarikan kebudayaan Indonesia yang semakin punah terkalahkan oleh kemajuan teknologi.

Implementasi desain didaktis dilaksanakan kedalam dua siklus, setiap siklus terdiri dari satu kali pertemuan pembelajaran. Implementasi siklus pertama dilakukan pada siswa kelas IV-C SDN Gunungpereng 1 dengan jumlah siswa 22 orang. Kegiatan pembelajaran dilaksanakan sesuai dengan rencana pelaksanaan pembelajaran yang telah dirancang dengan alokasi waktu 4 x 35 menit. Pembelajaran terdiri dari tiga bagian yaitu kegiatan pendahuluan, inti dan penutup. difokuskan untuk siswa memahami keliling persegi dan persegi

Kegiatan pembelajaran dilaksanakan dalam tiga kegiatan sesuai dengan rancangan desain bahan ajar, yaitu kegiatan pendahuluan, kegiatan inti, dan kegiatan penutup. Pada kegiatan pendahuluan, apersepsi yang dilakukan sama halnya dengan apersepsi pada tahap implementas desain awal. Guru dan 
siswa bertanya jawab mengenai jenis-jenis bangun datar yang siswa ketahui. Kemudian, peneliti menggali pengetahuan awal siswa sebagai prasyarat dalam mempelajari konsep keliling persegi dan persegi panjang.

Dalam bahan ajar berupa lembar aktivitas siswa yang telah dirancang oleh peneliti, kegiatan inti pembelajaran terdiri dari 3 aktivitas kegiatan. Dimana kegiatan pertama bertujuan untuk mengembangkan pengenalan siswa terhadap bangun datar persegi dan persegi panjang. Konteks yang terdapat dalam LAS, siswa mengamati gambar petak permainan oray-orayan kemudian siswa menyebutkan nama bangun datar yang tampak dari petak tersebut, kemudian siswa menggambarkan kembali bentuk petak tersebut pada kolom yang telah disediakan. Kegiatan kedua bertujuan untuk mengembangkan pemahaman siswa terhadap konsep keliling serta kelilng persegi panjang. Sebelum siswa mengaplikasikan rumus keliling persegi, siswa harus mampu menemukan rumus kelilng persegi dan persegi panjang tersebut terlebih dahulu. Dalam kegiatan dua siswa bermain melakukan permainan tradisional oray-orayan sedangkan, kegiatan tiga bertujuan untuk mengembangkan pemahaman siswa terhadap keliling persegi panjang. kegiatan tiga tidak berbeda jauh dengan kegiatan yang dilakukan dalam kegiatan 2.

Gambaran yang dapat diberikan berdasarkan implementasi siklus pertama adalah, respon siswa masih menunjukkan adanya hambatan belajar terkait konsep menghitung keliling persegi dan persegi panjang. Namun, tingkat hambatan belajar siswa tidak separah dengan hambatan belajar yang ditemukan pada tahap studi pendahuluan. Setelah peneliti melakukan refleksi desain didaktis awal, siswa ternyata banyak mengalami kesulita yang sama dengan studi pendahuluan. Siswa kesulitan dalam menyelesaikan soal-soal cerita yang berkaitan dengan menghitung keliling persegi dan persegi panjang. Kesulitan siswa yang muncul lebih diakibatkan karena keterbatasan pemahaman siswa pada konsep menghitung keliling persegi dan persegi panjang. Namun, data yang diperoleh dari hasil implementasi desain awal menggambarkan bahwa siswa mengalami peningkatan pemahaman dan kemampuan dalam menyelesaikan soal-soal terkait menghitung keliling persegi dan persegi panjang. permasalahan-permasalahan pada implementasi desain didaktis awal selanjutnya menjadi bahan pertimbangan untuk merevisi bahan ajar.

Implementasi siklus dua dilaksanakan pada siswa kelas IV SDN Mangkubumi pada hari Sabtu tanggal 12 Mei 2018 dengan jumlah siswa 22 orang. Peneliti sebelumnya melakukan analisis dan kajian terhadap hasil implementasi desain didaktis awal, kemudian melakukan revisi kekurangan-kekurangan yang terdapat pada desain awal. Revisi dilakukan pada sajian bahan ajar serta 
antisipasi didaktis pedagogis. Perubahan yang dilakukan salah satunya adalah perbaikan konteks butir latihan soal yang diberikan kepada siswa dikarenakan terdapat kekeliruan.

Pada dasarnya tidak ada desain didaktis sempurna yang mampu memenuhi kebutuhan siswa secara maksimal, dan mampu mmenghilangkan hambatan belajar siswa secara menyeluruh dan tuntas. Desain didaktis yang dirancang dalam sebuah penelitian harus selalu dikembangkan dan disesuaikan lagi dengan kebutuhan siswa di lapangan. Oleh karena itu, desain didaktis yang dirancang oleh peneliti dapat dikembangkan oleh guru ketika pembelajaran di kelas sesuai dengan situasi dan kondisi yang dibutuhkan.

Respon siswa terhadap desain didaktis konsep keliling persegi dan persegi panjang berbasis permainan oray-orayan terlihat membuat siswa lebih antusias saat melakukan kegiatan pembelajaran. Seperti yang telah diketahui bahwa karakteristik anak usia sekolah dasar masih senang bermain, sehingga desain didaktis ini dirancang untuk membuat kegiatan pembelajaran yang dapat menciptakan suasan pembelajaran yang menarik dan membuat pembelajaran lebih bermakna dengan siswa mengkonstruk pengetahuan siswa sendiri. Prediksi respon siswa yang muncul secara umum dapat dintisipasi dengan ADP yang telah dirumuskan. Baik itu ketika implementasi desain didaktis awal maupun ketika pelaksanaan implementasi desain didaktis revisi. Analisis yang dilakukan berdasarkan implementasi desain didaktis awal, peneliti melakuan perbaikan terhadap sajian bahan ajar termasuk prediksi respon siswa beserta antisipasi didaktis pedagogis untuk mencegah hambatan belajar siswa yang mungkin muncul saat proses pembelajaran. Dalam merancang desain didaktis guru melakukan repersonalisasi terhadap materi konsep keliling persegi dan persegi panjang. Proses berpikir yang dilakukan oleh guru tidak hanya terjadi saat proses menyampaikan materi ajar dalam proses pembelajaran, namun kemampuan guru untuk mempertimbangkan segala respon siswa dari setiap tindakan didaktis guru saat pembelajaran menjadikan kegiatan berlajar siswa lebih terkondisikan dengan baik. Terbukti dengan adanya peningkatan pemahaman siswa dan hasil belajar siswa maupun hasil siswa dalam mengisi lembar aktivitas siswa jika dibandingakan dengan saat studi pendahuluan maupun antara implementasi desain didaktis awal dan implementasi desain didaktis revisi.

\section{SIMPULAN}

Learning obstacle siswa pada materi keliling persegi dan persegi panjang terbagi kedalam lima tipe. Tipe satu, learning obstacle terkait dengan memahami bentuk bangun datar persegi dan persegi panjang. Tipe dua, learning obstacle terkait dengan menghitung keliling persegi. Tipe tiga, learning obstacle terkait dengan menghitung 
keliling persegi panjang. Tipe empat, learning obstacle terkait dengan menyelesaikan soal yang berkaitan dengan menghitung keliling persegi. Tipe lima, learning obstacle terkait dengan menyelesaikan soal yang berkaitan dengan menghitung keliling persegi panjang. hambatan belajar tersebut dapat diatasi dengan bahan ajar yang disusun oleh penliti yaitu desain didaktis berbasis permainan tradisional oray-orayan untuk mengembangkan kemampuan pemahaman siswa terhadap materi keliling persegi dan persegi panjang. Pembelajaran disajikan melalui lembar aktivitas siswa dapat mengurangi atau mengatasi hambatan belajar yang ada sebelumnya. Hasil desain awal dan desain revisi yang sudah diimplementasikan menunjukkan adanya pengembangan kemampuan siswa.

\section{DAFTAR PUSTAKA}

Aprianti, A. D. (2016). Desain Didaktis Pengelompokan Bangun Datar Untuk Mengembangkan Komunikasi Matematis siswa kelas II Sekolah Dasar. (Skripsi). Program S1 Pendidikan Guru Sekolah Dasar, Universitas Pendidikan Indonesia, Tasikmalaya.

Mulyani, Novi. (2016). Super Asyik Permainan Tradisional Anak Indonesia. Yogyakarta: DIVA Press.

Nur'aeni, E. (2008). Teori Van Hiele dan Komunikasi Matematik (Apa, Mengapa dan Bagaimana. Seminar Nasional Matematika dan Pendidikan Matematika (hlm. 124-137).

Suryadi, D. (2010). "Didactical Design Research (DDR) dalam Pengembangan
Pembelajaran Matematika." Prosiding Seminar Nasional Pembelajaran MIPA (hlm. 1-14). Malang: UM Malang.

Susanto, A. (2013). Teori Belajar dan Pembelajaran di Sekolah Dasar. Jakarta: Kencana Prenadamedia Group. 